\title{
Network mapping in the development of elephant conservation center in North Sumatra, Indonesia
}

\author{
ROSPITA ODORLINA P. SITUMORANG ${ }^{1,2, \vartheta}$, WANDA KUSWANDA ${ }^{2, v \vee}$ \\ ${ }^{1}$ Department of Forestry, National Chung Hsing University No.145, Xingda Road, South District, Taichung City 402, Taiwan, ROC \\ Tel.: +886- (0)4-22840345 ext 111, Fax.: + 886-(0)4-22873628, ‘email: pita_80s@yahoo.com; \\ ${ }^{2}$ Environmental and Forestry Research and Development Institute Aek Nauli, Jl. Raya Parapat 10.5, Parapat, Simalungun 21174, North Sumatra,

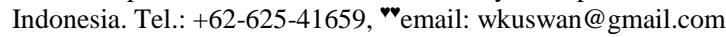

Manuscript received: 24 June 2019. Revision accepted: 6 September 2019.

\begin{abstract}
Situmorang ROP, Kuswanda W. 2019. Network mapping in the development of elephant conservation center in North Sumatra, Indonesia. Biodiversitas 20: 2858-2867. A project in the Aek Nauli Elephant Conservation Camp (ANECC) is being carried out to conserve Sumatran elephant handled by several institutions within the Ministry of Environmental and Forestry of Republic of Indonesia and other supporting stakeholders. A social networking analysis (SNA) had been carried out to analyze the social interactions of the stakeholders in the development of the ANECC. This research aimed at finding out the important actors in the network and describing at the social network gap in the development of ANECC objectives as conservation, and research, and ecotourism center. From the research, we found four institutions engaged in conservation, research, and animal health surveillance as the core actors and 19 other institutions as the periphery actors consisting of authorities, local government, businessmen, and local people. The study also found that the Environmental and Forestry Research and Development Institute Aek Nauli is the most influential actor in the network, and the National Planning Agency and Girsang Sipanganbolon Sub-district as the bridging actors who connect the supporting actors to the core actors. Conservation aspect is the most communicated in the network, followed by ecotourism, and research. Our research also found that conservation and research aspects have been handled by the appropriate institutions, however, ecotourism has not been handled by certain agencies responsible for the development of ecotourism. Hence, the study suggests that the core actors can consider binding cooperation with potential entrepreneurs on tourism around the site to develop ecotourism sector in ANECC.
\end{abstract}

Keywords: Actors, ANECC project, social interaction, social networking analysis, SNA

\section{INTRODUCTION}

Sumatran elephant (Elephas maximus sumatranus) population declining has resulted in categorization of Sumatran elephant as endangered species Appendix I since 1986 (IUCN 2013). The population decline is generally caused by human-elephant conflict due to the movement of elephants into agricultural, plantation, and residential areas caused by habitat loses which usually end with elephant trapping and killing (Zafir and Magintan 2006). Translocation of wild elephants from the conflict areas to the safer areas is one of efforts to overcome the decline of elephant populations.

Translocation of elephants to conservation centers is one of the ex-situ methods to prevent human-wildlife conflict between communities and elephants (Chartier et al. 2011; Daim 2001; Parr et al. 2008; Tipprasert 2002; Perera 2009; Zafir and Magintan 2006). Even though the elephants are not living in their natural habitat, the minimum requirements such as area, natural habitat, treatment, feeding, supervisors, and supporting facilities must be met by the elephant conservation managers (Meytasari et al. 2014). The elephant conservation center has several objectives including to preserve elephant population, to develop knowledge about elephants, and to provide educational and nature recreational sites (Daim 2001; Tipprasert 2002; Kontogeorgopoulos 2009;
Kuswanda et al. 2018).

Recently, a project on elephant conservation is being carried out in a research forest located around Toba Lake, namely Aek Nauli Elephant Conservation Camp (ANECC). Toba Lake is one of the famous tourism areas in Indonesia. The project begun in 2016 was intended to provide a suitable habitat for captive elephants. According to FORDA (2017), the idea of the project was initiated from the overpopulation problem of captive elephants at the Holiday Resort Elephant Training Center in Riau Province, Indonesia, as one of the training centers of catching elephants from conflict areas, particularly from Sumatra forests. Therefore, a better location was needed to meet the requirements standard for elephant breeding. Later, the Aek Nauli Special Purpose Forest Region (KHDTK Aek Nauli) has been agreed as the project location considered on its sufficient area, the natural conditions, and the security level.

The ANECC project belongs to Ministry of Environment and Forestry of the Republic of Indonesia which is run through a collaboration project involving three institutions including forest conservation service, research and development agency, and Sumatran wild animal supervisory organization. This collaboration has created social networking in the ANECC project which involves collaborating parties and other supporting parties through a wide array of social and economic interests.

Social networks are comprised of actors who are tied to 
one another through meaningful relations. These relations can be analyzed for structural patterns that emerge among these actors. Thus, analysts of social networks look beyond attributes of individuals to also examine the relations among actors, how actors are positioned within a network, and how relations are structured into overall network patterns (Prell et al. 2009). Social network analysis (SNA) represents a distinctive set of methodologies to map, to measure, and to analyze social relationships between people, teams, and organizations ( Hanneman and Riddle 2005; De Brún and McAuliffe 2018).

Social network management can allow people to get to know each other better which fosters a better relationship, to connect people, and to create a sense of trust, and responsibility toward each other (Keyes 2016). In natural resource utilization, network management can strengthen social capacity and integrate common goals on common resources (Borg et al. 2015; Situmorang 2018). In government projects, network management is learned to improve the project outcomes such as innovations, environmental control, integrated solutions, conflict resolutions, the robustness of the results, effectiveness of costs, time, and benefit increasing (Klijn et al. 2010).

Social network analysis in the ANECC project needs to be done in order to map the interactions, interests, tasks, and influences of the actors in the project. Social network mapping can reveal the gaps and problems which happen in the ANECC project, hence, it helps decision-makers in mapping problems in the network structure, planning and decision making (Lienert et al. 2013) through improving social capital. Hence, our study aimed to identified actors in the ANECC network, to map the social interaction in the ANECC project, as well as to measure and to compare how the project objectives in the field of conservation, research, and ecotourism have been communicated by the actors in the interactions through SNA. Through the network management, this study can figure out the social capital the ANECC network and can recommend suggestion to project managers on how to improve the output and the sustainability of the project through finding problems or gaps in the network.

\section{MATERIALS AND METHODS}

\section{Study area}

This research was carried out in the Aek Nauli Elephant Conservation Camp (ANECC) of the Aek Nauli Special Purpose Forest Region (Kawasan Hutan dengan Tujuan Khusus Aek Nauli, KHDTK) or the Aek Nauli experimental forest which is about 100 hectares. Due to the location of actors or institutions involved in the project, this research was also carried out in Medan, Pematangsiantar, Parapat (Simalungun District), and Aek Nauli (Sibaganding Village, Simalungun District), of North Sumatra Province, Indonesia. The data collected through structured interviews was intensively conducted in April 2017 until August 2017 and continued in September 2018.
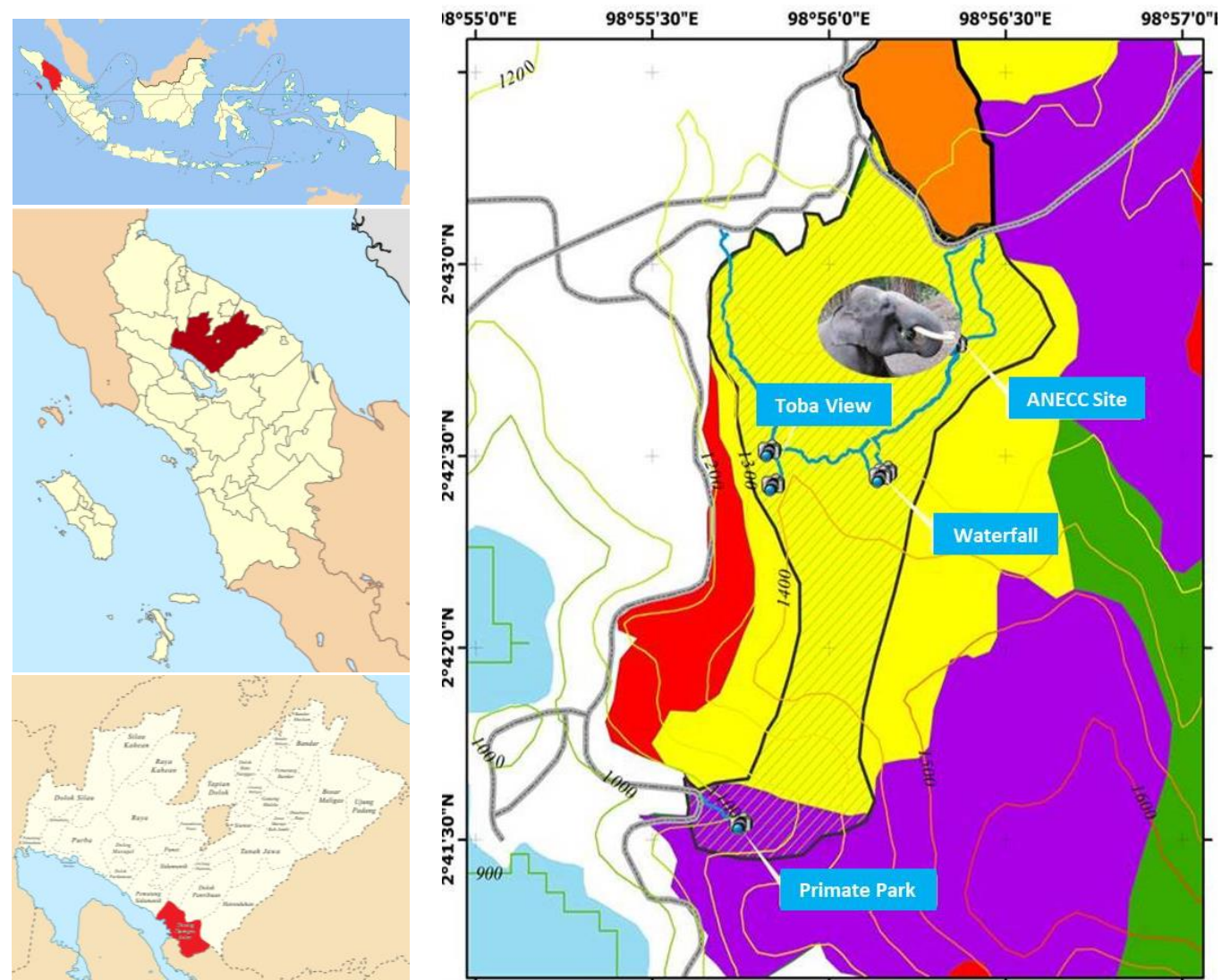

Figure 1. Elephant conservation center site location at the Aek Nauli Special Purpose Forest Region around Toba Lake, in Sibaganding Village, Girsang Sipangan Bolon Subdistrict, Simalungun District, North Sumatra, Indonesia 


\section{Procedures}

The document review of ANECC master plan was firstly conducted in this study to find out the description of the project's objectives, and the responsible managers and its collaborators. From the review, we found that there are three objectives of the ANECC Project, i.e.: conservation, research, and ecotourism, and three institutions acting as managers as well as collaborators of the ANECC Project, i.e.: The Natural Resource Conservation Agency of North Sumatra, The Environmental and Forestry Research and Development Institute Aek Nauli, and the Veterinary Society for Sumatran Wildlife Conservation (VESSWIC). These institutions were considered as the important institutions which later determined as the key actors. A total of 7 key respondents consisting of the project leaders and staffs of those three institutions selected by purposive sampling method were interviewed to get the in-depth information of the ANECC project purposes, roles, collaborators, and networks. Information from the key respondents was used to develop questionnaire, to carried out the focused group discussion (FGD), to visit the institutions or organization which involve in the ANECC project, and to communicate via telephone with institutions that cannot be reached by direct meeting.

One of the ways to collect data and information in this study was by conducting FGD. The FGD conducted at the Environmental and Forestry Research and Development Institute Aek Nauli office which is adjacent to the project site was attended by 13 institutions consisting of ANECC managers and collaborators, central and local government institutions, tourism businesses, and local communities. The FGD aimed to obtain more detailed information about the progress of the project, to know the linkages of each institution of the FGD participants with other actors, and to explore the potential conflicts and gaps that occur during project implementation. At the end of the discussion, each participant filled out a questionnaire containing questions about to whom and from whom each institution gave and received information, and in which area of ANECC's objectives that they have the interest and can influence the project, and in what areas that the actors communicated with other actors.

Data and information of other stakeholders (institutions or organizations) that have relation to the ANECC project based on the information from the FGD audiences were recorded. The activity was then continued by interviews to the stakeholders who did not attend the FGD at their location, while other stakeholders that cannot be met directly due to the distance factor were interviewed through telephone connection. A total of 126 respondents during the research was interviewed which represented their institutions. Until the research was done, we found 23 institutions connected in the ANECC project which are later called as actors in this research.

\section{Data analysis}

The social network was analyzed by using UCINET 6 software to generate network maps and to compute relevant network metrics. SNA provides tools for understanding embeddedness and power structures within any group links between social capital and collective action (Borgatti and Foster 2003; Siegel 2009). In particular, a network is formed by nodes (or vertices or vertexes) that represent the involved actors, and edges (or links) that express the linkage among these nodes (De Martí and Zenou 2009; Denny 2014). After the identification of actors, the $23 \times 23$ linkages matrix was provided to denote the number of actors and their interaction. When a tie is either present or absent, the relation is dichotomous, taking on values of 0 or 1. After completion of the actor linkage matrix, then, the next step in the ANECC analysis was determining network density and network centrality in order to understand the density of interactions and to find out the power of actors, and mapping the network to figure out the overall picture of the network and their interactions (Butts 2008; De Brún and McAuliffe 2018; García-Amado et al. 2012).

\section{Network density $(\rho)$}

Network density is an important network-level measure, which is able to explain the general level of connectedness in a network (Oliveira and Gama 2012). Network density basically represents the actual number of ties in a network as a ratio of the total maximum ties that are possible with all the nodes of the network. A fully dense network has a network density value of 1 , which indicates that all nodes are connected to each other, and 0 or near 0 indicates that it is a sparsely-knit network (Chung et al. 2005).

$$
\rho(\mathrm{G})=\frac{m(G)}{m_{\operatorname{mix}}(G)} \quad 0<\rho<1
$$

Where, $m$ is the number of edges in the network and $m_{\max }(G)$ denotes the number of possible edges, which is $\frac{n(n-1)}{2}$ for undirected networks and $n(n-1)$ for directed ones (Oliveira and Gama 2012).

\section{Centrality}

One of the most important issues in the complex network analysis is the problem of extracting central members of the network known as centrality (Wasserman and Faust 1994). Centrality analysis is used to review the power and influence of each actor. The actor with the highest centrality score indicates the actor with the greatest structural importance in networks, and the actor would be expected to have a key role in simulated and real-world behavior. Centrality consists of degree of centrality, closeness centrality, and betweenness centrality.

Degree of centrality is one of the simplest and the most intuitive centrality measures. It is the number of links directly connecting node $x$ with other nodes in the network (Carrington et al. 2005; Wasserman and Faust 1994). In an undirected graph, it is the number of edges connected to the single node. DC is expressed by the normalized number of neighbors that are connected with the given person:

$$
\mathrm{DC}(x)=\frac{d(x)}{m-1}
$$

Where, $d(x)$ is the number of the first level neighbors that are directly connected with node $x$, and $m$ denotes the total number of members in the social network. 
Closeness centrality is quantifying the minimal path from a given node to another. It shows the individual's (actor) ability to be able to contact or influence all individuals in the system (Cindoswari 2017; Song et al. 2018). It measures how many steps (ties) are required for a particular actor to access every other actor in the network (Denny 2014).

$$
C_{C}(x)=\frac{n-1}{\left.\sum d(x y)\right\}}
$$

Where, $n$ is the number of actors in the network, and $d$ $(x, y)$ is the shortest-path distance between actors $x$ and $y$.

Betweenness centrality is based on counting the number of geodesics (the shortest paths) $\mathrm{g}_{\mathrm{xy}}$ between actors $x$ and $y$, and looking at the number $g_{x y}(z)$ which travel via actor $z$ :

$$
\left(\mathrm{C}_{\mathrm{B}}\right)=\frac{2}{(n-\mathbb{1})(n-2)} \sum_{X \neq z} \sum_{X<y \neq x}\left(\frac{g_{x y}(z)}{g_{x y}}\right)
$$

After finishing the network mapping, the last step was revealing the interaction of actors to the ANECC purposes in conservation, research, and ecotourism purposes. Through centrality analysis to each goal, it describes how important is each sector to the actors (institutions) and finds out whether each purpose has been handled maximally or minimally within the project development. All the quantitative and qualitative data were combined to interpret the importance of each goal in the ANECC network.

\section{RESULTS AND DISCUSSION}

\section{Identification of actors}

Interaction of several actors, individually and across organizations from the initiation to the operation happens in the ANECC project. From the document review, we found three institutions collaborating in the ANECC development. They are the Natural Resource Conservation Agency of North Sumatra, the Environmental and Forestry Research and Development Institute Aek Nauli, and the Veterinary Society for Sumatran Wildlife Conservation (VESSWIC).

In two years since the project began, the ANECC network has been wider between government organizations and other organization consisting of local government organization, NGO, local people, and various private businesses relating to some needs in the completion of the project and the continuity of the program as shown in Table 1.

The central government institutions including the Natural Resource Conservation Agency of North Sumatra and the Environmental and Forestry Research and Development Institute Aek Nauli shown in Table 1 are government institutions that belong to the Ministry of Environment and Forestry. To understand their institutional structure, the organization structure is presented in Figure 2.

As a national-scale government project, the government planning and funding agencies i.e. Ministry of Finance, and National Planning Agency are automatically connected to the ANECC project particularly in planning, regulating, funding, and evaluation. While, the local government institutions and the local people were organizations which were later connected to the project because the site location is at Sibaganding Village area. The ANECC managers interact with them regarding the local regulations, the security of the project, and promotion to the local residents to support the programs, labor demand, and tourism development. Meanwhile, the local government and surrounding communities are interested to be involved because they want to get economic and social benefits from the project, such as opportunities for productive businesses around the ANECC that can increase income, and at the same time increases employment.

The VESSWIC is a non-governmental organization consisting of veterinarians who have concern for the conservation of Indonesian wildlife, especially Sumatran wildlife. The cooperation of this NGO in monitoring and supervision of Sumatran wild animal health with the Natural Resources Conservation of North Sumatra Institution has been going on for a long time. Hence, that is the reason why the VESSWIC is involved in the ANECC project as one of the collaborators. Other actors such as private businesses such as constructors and suppliers, oil palm company, feed provider, and tourism company are connected to the ANECC project due to the business interests. Lastly, the universities connected to ANECC project are local universities which are interested in doing research on Sumatran elephant in the location.

\section{ANECC network mapping \\ Network density}

Connectedness between the actors is based on various interests related to constructions, elephant translocation, elephant maintenance, researching, and development plans to the ecotourism model. The density that shows the level of connectedness in the ANECC network can be seen in Table 2. The overall density of ANECC network is 0.209 of $0-1$ scale $(20.9 \%)$. This means that the density is still relatively low if compared to the potential connectivity of various parties (only $20.9 \%$ of $100 \%$ ) in the development of this elephant conservation. The result shows that most of the actors are not connected to more than one actor.

\section{Centrality}

The centrality measurement was carried out to determine the important actors and the role of each actor in the network as presented in Table 3.

In Table 1 and Table 3, we grouped the actors based on their roles and their interest in the network. Among the actors, the highest centrality actor goes to the Environmental and Forestry Research and Development Institute Aek Nauli. It denotes that this actor is the most connected actor with other actors both in receiving and giving information (degree of centralization), the highest link that can be through to access every other actor in the network (closeness centralization), and the highest intermediary role (linker) in the network (Carrington et al. 2005; Song et al. 2018). This is reasonable because this actor as presented in Table 1 has a role as one of the collaborators, initiator, planner, and implementer in the 
project (particularly in research aspect). The site project location which is close to the Environmental and Forestry Research and Development Institute Aek Nauli makes this institution get more interaction to other parties with later are interested in the elephant conservation development such as local government, local people, and local businessmen to support the project. Another reason is that before the ANECC project released, this institution has also carried out a number of ecotourism and research activities in the elephant area and its surroundings such as camping, edutainment, and jungle tracking. Therefore, this institution already has a network with the local people, schools, and the local government.

Table 2. Density of ANECC network

\begin{tabular}{lllll}
\hline & Density & $\begin{array}{l}\text { Number } \\
\text { of ties }\end{array}$ & $\begin{array}{l}\text { Standard } \\
\text { deviation }\end{array}$ & Alpha \\
\hline ANECC Network & 0.209 & 106 & 0.407 & 0.859 \\
\hline
\end{tabular}

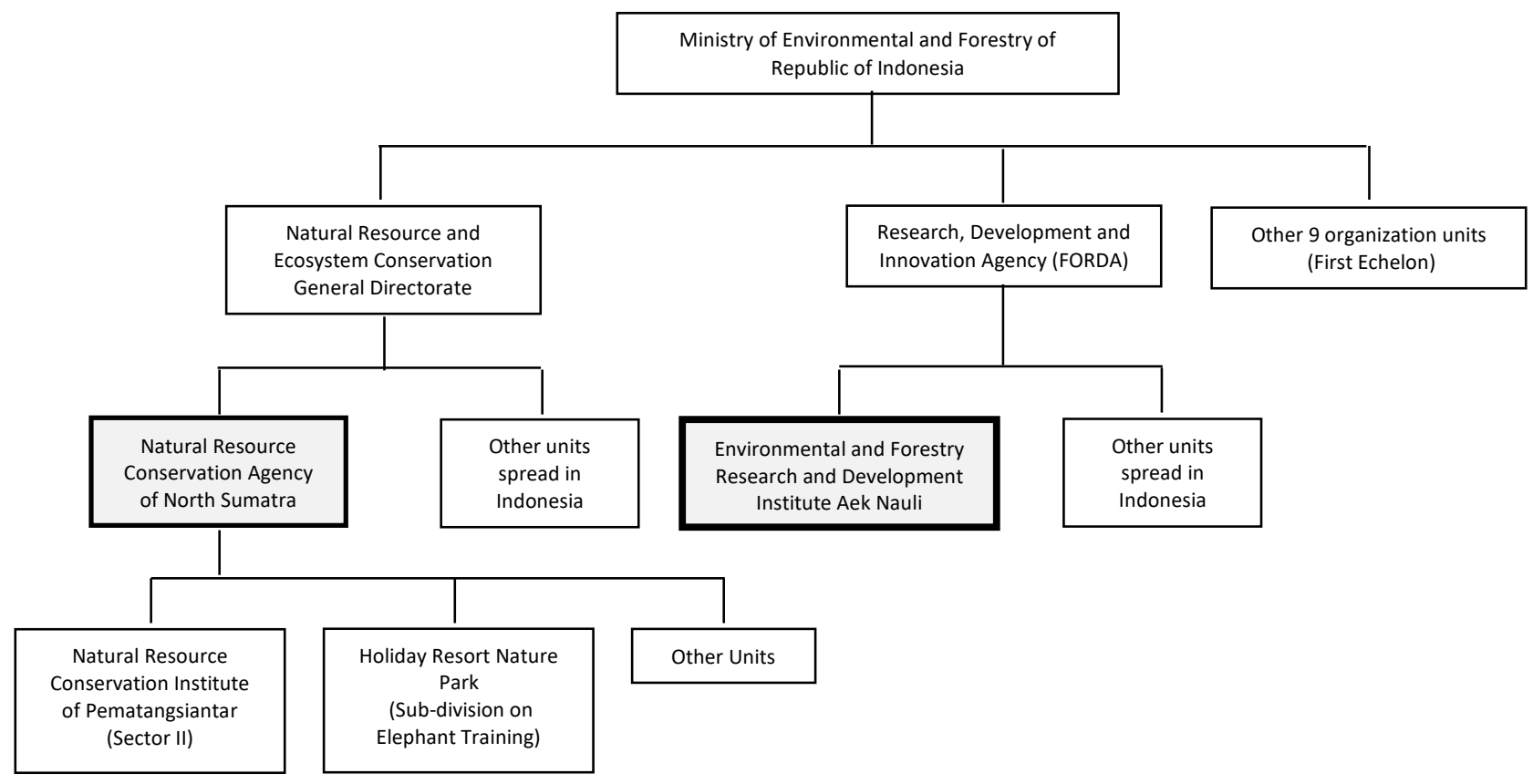

Figure 2. Position of actors in the organizational structure (MoEFRI 2015). Note: The bold boxes are the collaborators in the agreement document
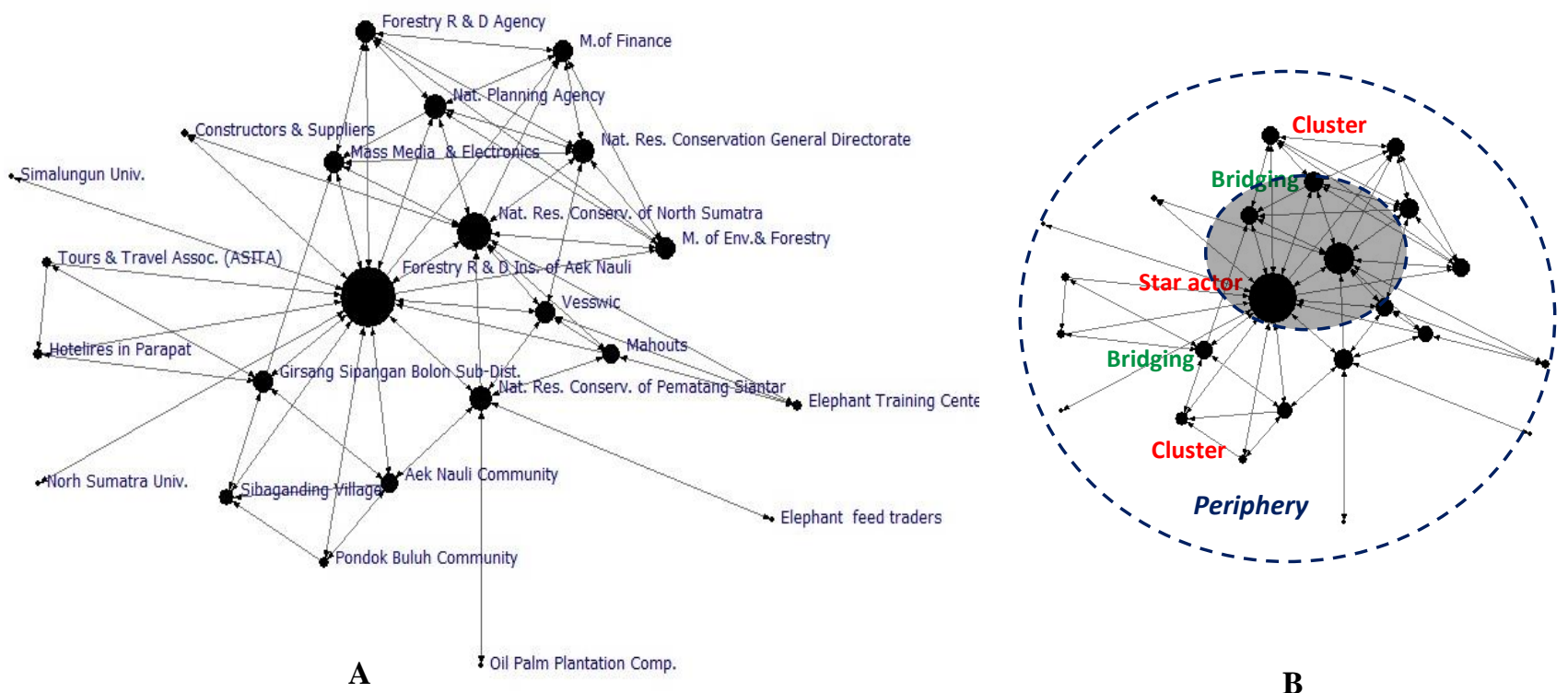

Figure 3. ANECC network structure. A. Network structure by a degree of centrality, B. Network structure Analysis (Core-Periphery Network structure pattern) 
Table 1. Actors/stakeholders that have relation to the ANECC development

\begin{tabular}{|c|c|c|c|c|c|}
\hline Actors/stakeholders & $\begin{array}{l}\text { Organization } \\
\text { Categories }\end{array}$ & Specialty & Roles & $\begin{array}{l}\text { Area of interest in the } \\
\text { ANECC project }\end{array}$ & Remarks \\
\hline Ministry of Environmental and Forestry & Central government & Forestry & $\begin{array}{l}\text { The regulator at the national } \\
\text { level, facilitator, evaluator }\end{array}$ & $\begin{array}{l}\text { Forest resource conservation, } \\
\text { research }\end{array}$ & \multirow{5}{*}{$\begin{array}{l}\text { Authority level actors } \\
\text { (Top management based on the } \\
\text { authority and structural institution. } \\
\text { The authority has direct command } \\
\text { to the lower level institution) }\end{array}$} \\
\hline Ministry of Finance & Central government & Finance & $\begin{array}{l}\text { The regulator at the national } \\
\text { level, funder, evaluator }\end{array}$ & Social-economic growth & \\
\hline National Planning Agency & Central government & General (Planning) & $\begin{array}{l}\text { The regulator at the national } \\
\text { level, facilitator, evaluator }\end{array}$ & $\begin{array}{l}\text { Conservation, research, tourism } \\
\text { development }\end{array}$ & \\
\hline $\begin{array}{l}\text { Natural Resource and Ecosystem } \\
\text { Conservation General Directorate }\end{array}$ & Central government & Conservation & $\begin{array}{l}\text { Regulator, facilitator, } \\
\text { evaluator. }\end{array}$ & Conservation & \\
\hline $\begin{array}{l}\text { Forestry Research and Development } \\
\text { Agency }\end{array}$ & Central government & Research & $\begin{array}{l}\text { The regulator at the national } \\
\text { level, facilitator, evaluator. }\end{array}$ & Research & \\
\hline $\begin{array}{l}\text { Natural Resource Conservation Agency of } \\
\text { North Sumatra }\end{array}$ & & Conservation & $\begin{array}{l}\text { Collaborator, initiator, } \\
\text { planner, implementer }\end{array}$ & Elephant Conservation & \multirow{4}{*}{$\begin{array}{l}\text { Implementer } \\
\text { The institutions are under the } \\
\text { command of the higher institution. } \\
\text { Technical Institutions who execute } \\
\text { the project }\end{array}$} \\
\hline $\begin{array}{l}\text { Natural Resource Conservation Institute of } \\
\text { Pematangsiantar (Sector II, Pematangsiantar) }\end{array}$ & Central government & Conservation & Implementer & Elephant Conservation & \\
\hline & Central government & Research & $\begin{array}{l}\text { Collaborator, initiator, } \\
\text { planner, implementer }\end{array}$ & $\begin{array}{l}\text { Research, education } \\
\text { development, ecotourism }\end{array}$ & \\
\hline Elephant Training Center (Holiday Resort) & Central government & Conservation & Elephant training & Elephant conservation & \\
\hline $\begin{array}{l}\text { Veterinary Society for Sumatran Wildlife } \\
\text { Conservation (VESSWIC) }\end{array}$ & $\begin{array}{l}\text { Non-government } \\
\text { Organization }\end{array}$ & Conservation & $\begin{array}{l}\text { Collaborator, initiator, } \\
\text { planner, implementer, }\end{array}$ & Elephant health and wealth & Implementer, NGO \\
\hline Mahouts & Professional association & Conservation & Elephant maintenance & Conservation & Implementer \\
\hline Constructors and suppliers & Entrepreneur & Construction & $\begin{array}{l}\text { Implementer on } \\
\text { infrastructure construction }\end{array}$ & Construction/economic & Cooperate with the main actors \\
\hline Girsang Sipanganbolon Subdistrict & Local government & Public administrator & $\begin{array}{l}\text { The regulator at the local } \\
\text { level }\end{array}$ & $\begin{array}{l}\text { Ecotourism, education, and } \\
\text { regional development }\end{array}$ & Local authority actors \\
\hline Sibaganding Village & Local government & Public administrator & $\begin{array}{l}\text { The administrator at the } \\
\text { local level }\end{array}$ & $\begin{array}{l}\text { Tourism, education, and } \\
\text { economic }\end{array}$ & \\
\hline $\begin{array}{l}\text { Tour and Travel Association (ASITA) } \\
\text { Hotel entrepreneurs }\end{array}$ & $\begin{array}{l}\text { Entrepreneur community } \\
\text { Entrepreneur community }\end{array}$ & $\begin{array}{l}\text { Tourism } \\
\text { Tourism }\end{array}$ & $\begin{array}{l}\text { Promotion } \\
\text { Promotion }\end{array}$ & $\begin{array}{l}\text { Tourism and economic } \\
\text { Tourism and economic }\end{array}$ & Private business and association \\
\hline $\begin{array}{l}\text { Oil Palm Plantation Company (PTPN IV) } \\
\text { Elephant feed traders }\end{array}$ & $\begin{array}{l}\text { National company } \\
\text { Entrepreneur }\end{array}$ & $\begin{array}{l}\text { Plantation } \\
\text { Economic business }\end{array}$ & $\begin{array}{l}\text { Feed provider } \\
\text { Feed providers }\end{array}$ & $\begin{array}{l}\text { Economic } \\
\text { Economic }\end{array}$ & Company and local business \\
\hline Aek Nauli Community & Local community & Local community & Employee, feed supplied & $\begin{array}{l}\text { Social and economic } \\
\text { development (ecotourism) }\end{array}$ & $\begin{array}{l}\text { Local communities are commanded } \\
\text { by local authority actors }\end{array}$ \\
\hline Pondok Buluh Community & Local community & Local community & Feed provider & Education and economic & \\
\hline $\begin{array}{l}\text { North Sumatra University } \\
\text { Simalungun University }\end{array}$ & $\begin{array}{l}\text { Educational institution } \\
\text { Educational institution }\end{array}$ & $\begin{array}{l}\text { Education and research } \\
\text { Education and research }\end{array}$ & $\begin{array}{l}\text { Implementer } \\
\text { Implementer }\end{array}$ & $\begin{array}{l}\text { Education } \\
\text { Education }\end{array}$ & \\
\hline Mass media and electronics & Journalistic company & Reporting & Promotion & $\begin{array}{l}\text { Ecotourism, conservation, } \\
\text { social-economic development }\end{array}$ & Local and national media \\
\hline
\end{tabular}


Table 3. Degree of centrality, closeness, and betweenness

\begin{tabular}{|c|c|c|c|c|c|c|}
\hline \multirow{2}{*}{ Actors/stakeholders } & \multicolumn{2}{|c|}{$\begin{array}{l}\text { Degree of } \\
\text { centrality }\end{array}$} & \multicolumn{2}{|c|}{ Closeness } & \multirow{2}{*}{$\begin{array}{l}\text { Between- } \\
\text { ness }\end{array}$} & \multirow{2}{*}{ Remarks } \\
\hline & In & Out & In & Out & & \\
\hline Ministry of Environmental and Forestry & 5.00 & 6.00 & 55.00 & 40.74 & 2.83 & Authority \\
\hline Ministry of Finance & 4.00 & 6.00 & 55.00 & 37.93 & 1.32 & Authority \\
\hline National Planning Agency & 6.00 & 6.00 & 55.00 & 54.66 & 14.38 & Authority \\
\hline Natural Resource and Ecosystem Conservation General Directorate & 7.00 & 7.00 & 47.83 & 44.90 & 9.99 & Authority \\
\hline Forestry Research and Development Agency & 6.00 & 6.00 & 53.66 & 50.00 & 13.35 & Authority \\
\hline Natural Resource Conservation Agency of North Sumatra & 10.00 & 10.00 & 64.71 & 57.90 & 59.60 & Implementer \\
\hline Natural Resource Conservation Institute of Pematangsiantar & 7.00 & 6.00 & 55.00 & 55.00 & 89.39 & Implementer \\
\hline $\begin{array}{l}\text { Environmental and Forestry Research and Development Institute Aek } \\
\text { Nauli }\end{array}$ & 15.00 & 16.00 & 78.57 & 75.68 & 271.69 & Implementer \\
\hline Elephant Training Center (Holiday Resort) & 3.00 & 3.00 & 41.51 & 40.74 & 0.00 & Implementer \\
\hline Veterinary Society for Sumatran Wildlife Conservation (VESSWIC) & 6.00 & 6.00 & 57.90 & 55.00 & 26.09 & Implementer \\
\hline Mahouts & 5.00 & 4.00 & 44.90 & 53.66 & 7.38 & Implementer \\
\hline Constructors and Suppliers & 2.00 & 2.00 & 48.89 & 47.83 & 0.00 & Implementer \\
\hline Girsang Sipanganbolon Sub-district & 6.00 & 5.00 & 53.66 & 52.38 & 45.98 & Local authority \\
\hline Sibaganding Village & 2.00 & 4.00 & 47.83 & 46.81 & 1.00 & Local authority \\
\hline Tour and Travel Association (ASITA) & 3.00 & 1.00 & 33.33 & 47.83 & 0.00 & Local business \\
\hline Hotel entrepreneurs & 2.00 & 2.00 & 33.85 & 46.81 & 0.00 & in tourism \\
\hline Oil Palm Plantation Company & 1.00 & 1.00 & 36.07 & 36.67 & 0.00 & $\begin{array}{l}\text { Elephant feed } \\
\text { supplier }\end{array}$ \\
\hline Elephant feed traders & 1.00 & 1.00 & 36.07 & 36.67 & 0.00 & $\begin{array}{l}\text { Elephant feed } \\
\text { supplier }\end{array}$ \\
\hline Aek Nauli Community & 5.00 & 4.00 & 50.00 & 53.66 & 12.45 & Local people \\
\hline Pondok Buluh community & 3.00 & 2.00 & 45.83 & 45.83 & 0.00 & Local people \\
\hline North Sumatra University & 1.00 & 1.00 & 44.90 & 44.00 & 0.00 & $\begin{array}{l}\text { Educational } \\
\text { Institution }\end{array}$ \\
\hline Simalungun University & 1.00 & 1.00 & 44.90 & 44.00 & 0.00 & $\begin{array}{l}\text { Educational } \\
\text { Institution }\end{array}$ \\
\hline Mass media and electronics & 4.00 & 6.00 & 55.00 & 50.00 & 6.57 & $\begin{array}{l}\text { Promotion } \\
\text { media }\end{array}$ \\
\hline
\end{tabular}

Table 4. Comparison of density, number of relationships and degree of centrality in each sector

\begin{tabular}{lccc}
\hline Measurements & Conservation & Research & Ecotourism \\
\hline Density & 0.132 & 0.075 & 0.107 \\
Total ties & 67 & 38 & 54 \\
Number of interacting & 20 & 16 & 19 \\
actors (of 23 actors) & & & \\
Degree of centrality & & & \\
$\quad$ Mean & 2.913 & 1.652 & 2.348 \\
Maximum (out) & 10 & 10 & 8 \\
Maximum (in) & 10 & 10 & 10 \\
Minimum & 0 & 0 & 0 \\
\hline
\end{tabular}

The Natural Resource Conservation Agency of North Sumatra as one of the collaborators, initiator, planner, and implementer in the project (particularly in conservation sphere) is in the second position. Based on the history of the project which is more focus on elephant conservation, it will create a question why this institution is not in the highest centrality in the network if we pay attention to its important role in this project. The organization structure in Figure 2 and distance factor will answer the question. The
Natural Resources Conservation of North Sumatra shares the duties to the Natural Resources Conservation Institute of Pematangsiantar (actor no. 7) as the lower level in the same institution (Figure 2). This institution which is closer to the site project can be more connected to local businessmen such as supplier, feeder, and local people.

In the authority group, the Natural Resource and Ecosystem Conservation General Directorate (actor no. 4) seem to have the highest degree of centrality. This institution is the actor who is most connected with other actors as compared to other authority actors. The ANECC development is a project which is mainly focused on conservation activities, hence, the Natural Resource and Ecosystem Conservation General Directorate mostly interacts with other actors such as with the government institutions in the higher structural level to ask for inputs, the government institutions in the same structural level to synergize the project plans and supporting regulation, the government institutions in the lower level to guide and supervise the project, and the NGO to collaborate and to monitor the elephant health.

Based on the closeness centralization and betweenness centralization in the authority group, National Planning Agency is the closest actor to reach other actors among 
other authority actors. This institution also acts as an intermediary agent or information broker by its high betweenness centrality (Singh et al. 2015) whose role is to bridge the authority actors to the implementing actors in the project. The National Planning Agency is a central institution that has a strategic role in evaluating and ratifying all planning concepts coming from institutions from various ministries. According to its central position, the National Planning Agency has a role to facilitate institutions from different divisions (conservation, research, and ecotourism) to meet and to synergize the program. Additionally, this institution also plays role as mediator to avoid conflicts of interest, and to convey the project planning to the financial management institution.

In the local level, Girsang Sipanganbolon Sub-district has fairly high betweenness centrality in the ANECC network. It means that this actor also plays roles as agent or broker. Its function as a local government institution has involved them to play a role in providing local regulations related to regional development, local community involvements, and security supervisory. Their connection to entrepreneurs will make it easier for implementers to connect to tourism entrepreneurs to be involved in ecotourism sector such as in the development of tourism concepts, tourism support facilities, souvenir centers which that do not exist yet within the ANECC site. As the leader and regulator in the Lake Toba tourism area, this actor also has potential to promote the elephant center as a new tourist icon around Toba Lake.

Through those explanations, we provide sociogram presented in Figure 3 to explain clearly about the relationships of actors in the ANECC network. The structure is the visualization of actor's interaction through giving, receiving, reciprocity (symbolized by lines and direction of the arrows) among the actors symbolized by nodes (Denny 2014).

In general, the network structure formed in the ANECC project in Figure 3 is a core-periphery structure. In coreperiphery structure, the network is divided into two areas, core area and periphery area. The core is a dominant central cluster, while the periphery has relatively few connections (Borgatti and Everett 1999; Hoppe and Reinelt 2010; Wu and Jin 2016). The Environmental and Forestry Research and Development Institute Aek Nauli which is in the core area has the highest centrality value called as star actor or central actor (Bodin and Crona 2009; Hanneman and Riddle 2005; Ruhnau 2000; Yang and Tang 2004). Besides forming a core-periphery structure, there are also two clusters formed in the ANECC network consisting of authority groups and local community groups (Figure 3. B). Kadushin (2011) mentioned that those clusters are formed on the basis of structurally equivalent in the network. It means that nodes (actors) that have similar patterns or relationships with other nodes are grouped together. Furthermore, the clusters are connected to the central actors by the bridging actors (National Planning Agency in the authority group and Girsang Sipanganbolon Sub-district in the local group) as it is indicated by the betweenness centrality value in each group (Table 3).

\section{Centrality based on sector in the ANECC network}

The ANECC project is a collaboration project aiming at developing Sumatran elephant conservation, research center, and ecotourism. Density and centrality sector in the ANECC network presented in Table 4 was carried out to reveal the importance level of the three sectors based on the actors' interest, roles, and influences the social interaction.

Based on Table 4, conservation is the aspect that most of the actors interacted with in the network. Of course, this is in accordance with the main objectives of development of the elephant center to conserve captive elephant (Daim 2001; Laohachaiboon 2010; Meytasari et al. 2014; Nyhus et al. 2000). It is also done at the ANECC to ensure a viable habitat and at the same time to maintain Sumatran elephants. Beside for conservation, ecotourism seems to receive considerable attention in the interaction. Even though only 2 institutions (ASITA and Hotel entrepreneurs in Parapat) that have basic specification in tourism (Table 1), 54 ties coming from 19 actors who give and receive information on ecotourism are created in the network. It means that ecotourism development is attractive to the most actors even though the duties and functions of the agencies are not in this sector. Lastly, the research sphere is the lowest aspect discussed by actors. This is reasonable because this field is a specific field, where there are not many people/institutions that have capability to be involved in.

In conclusion, SNA analysis has been widely used to find out the relationships of various stakeholders in natural resource management, whose purpose is to figure out the network structure and roles of each actor in the network (Bodin and Crona 2009; Bodin et al. 2011; Newman and Dale 2007; Prell et al. 2009). The elephant conservation center development located at Aek Nauli experimental forest (KHDTK Aek Nauli) is a project involving forest managers from different stakeholders to conserve Sumatran elephant which is now also to cope tourism management regarding the need of to support tourism around Toba Lake.

Until September 2018, there were 23 institutions from central government institutions, local government institutions, business institutions, academics and local communities who have social interactions in developing elephant conservation center at Aek Nauli. Among the 23 institutions, there were several institutions that have important roles in the network analyzed by their activities in receiving and providing information to all related actors (agencies/institutions) in the ANECC network. The Natural Resources Conservation Agency of North Sumatra, the Natural Resources Conservation Institute of Pematangsiantar, the Environmental and Forestry Research and Development Institute Aek Nauli, and VESWICC are the top four actors play roles as core actors based on their degree of centralization, closeness centralization, and betweenness centralization (Bodin and Crona 2009; Hanneman and Riddle 2005; Janssen et al. 2006; Prell et al. 2009; Yang and Tang 2004). Among the four, the Environmental and Forestry Research and Development Institute Aek Nauli is the most important actor which has the strategic position in the network that can be maximized to directly handle the project as well as to bridge various 
stakeholders that have been involved and potentially to be involved in the project. This strategic position is supported by various reasons such as this institution is one of the collaborators of the three collaborators who initiated and actualized the project, the project locations that are located on the land managed by this agency, the project location adjacent to this institution, and the development of ecotourism that already existed before the elephant project was implemented. Hence, the Ministry of Environmental and Forestry of Republic of Indonesia as the project owner can maximize the strategic role of the Environmental and Forestry Research and Development Institute Aek Nauli to enhance the comprehensive objectives of ANECC development.

Besides determining the central actors, this research also reveals the actors who act as the bridging actors or the brokers or middlemen based on their role as the agents in conveying information to other actors (Newman and Dale 2005; Otte and Rousseau 2002; Singh et al. 2015). In the ANECC network, two different groups at the different service level are formed where each group has a bridging actor towards the central actors, i.e. bridging actor in authority cluster at central level (National Planning Agency) and bridging actor in actor local cluster (Girsang Sipanganbolon Sub-district). The ANNEC project, which was initiated by the Ministry of Environmental and Forestry for conservation and research on captive elephants which later developed to support Lake Toba as national priority tourism, have risen actor in the authority level functioning as bridge and mediator between conservation institutions and research under the Ministry of Environmental and Forestry. The role of the mediator is very important in minimizing conflicts of interest between two institutions that have the same level in this project. In the local level, the Girsang Sipanganbolon Sub-district bridging actor can be maximized by the project managers to increase the output of this project especially in connecting tourism actors, supporting security and sustainability from the local communities around the project site, and as a promotional agent to visitors in their area. The bridging actors have strategic role to bridge the outside actors who have potential to be involved in the management of elephant conservation.

Finally, we used network density and degree of centralization to reveal the overall interaction in conservation, research, and ecotourism to reveal the interaction gap in the network which is done in previous studies (Kunz et al. 2017; Orrell et al. 2018). From the three areas, conservation is the more communicated in the network as the highest density and centrality, followed by ecotourism, and research. From our study, conservation and research area have been managed by institutions that have adequate resources such as conservation and research centers. Hence, the project objectives on these aspects can be properly addressed. Unlike the field of tourism, there seem to be no specific institutions to handle it since the project begun in late 2016. Although most of the institutions in the ANECC's network (19 from 23 institutions) interacted to manage ecotourism, there are no specific institutions that have concern to it. It means that it is not maximal to take over the ecotourism management without hiring another institution to develop better management. The consideration is that the ANECC has been planned to be developed as one of the tourist icons around Lake Toba which would later require serious handling from natural tourism expert to achieve sustainability.

\section{ACKNOWLEDGMENTS}

The authors express their deepest gratitude to the Environmental and Forestry Research and Development Institute Aek Nauli that has facilitated this research, Natural Resources Conservation of North Sumatra, and Veterinary Society for Sumatran Wildlife Conservation (VESSWIC) have collaborated in the management of ANECC. We also thank the Litkayasa Technicians for their help during data collection and other research activities.

\section{REFERENCES}

Bodin O, Crona BI. 2009. The role of social networks in natural resource governance: What relational patterns make a difference? Glob Environ Ch 19 (3): 366-374.

Bodin O, Ramirez-Sanchez S, Ernstson H, Prell C. 2011. A social relational approach to natural resources governance. In: Bodin O, Prell C (eds.). Social Network and Nat Res Management. Cambridge University Press, Cambridge, UK.

Borg R, Toikka A, Primmer E. 2015. Social capital and governance: A social network analysis of forest biodiversity collaboration in Central Finland. For Policy Econ 50: 90-97.

Borgatti SP, Everett MG. 1999. Models of core/periphery structures. Soc Netw 21: 375-395.

Borgatti SP, Foster PC. 2003. The network paradigm in organizational research: A review and typology. J Manag 29 (6): 991-1013.

Butts CT. 2008. Social network analysis: A methodological introduction. Asian J Soc Psychol 11 (1): 13-41.

Carrington PJ, Scott J, Wasserman S. 2005. Models and methods in social network analysis (Vol. 28). Cambridge University Press, Cambridge, UK.

Chartier L, Zimmermann A, Ladle RJ. 2011. Habitat loss and humanelephant conflict in Assam, India: Does a critical threshold exist? Oryx 45 (4): 528-533.

Chung KK, Hossain L, Davis J. 2005. Exploring socio-centric and egocentric approaches for social network analysis. In: Proceedings of the 2nd International Conference on Knowledge Management in Asia Pacific, Putra World Trade Center, Kuala Lumpur.

Cindoswari AR. 2017. Analisis struktur dalam jaringan komunikai dalam adaptasi ekonoi, sosial, dan budaya pada Paguyuban Babul Akhirat di Kota Batam. J Komunikasi 10 (2): 129-144. [Indonesian]

Daim MS. 2001. The care and management of domesticated elephants in Malaysia. Giants on Our Hands: Proceeding The International Workshop on The Domesticated Asian Elephant, Bangkok, Thailand.

De Brún A, Mc Auliffe E. 2018. Social network analysis as a methodological approach to explore health systems: A case study exploring support among senior managers/executives in a hospital network. Int J Environ Res Publ Health 15 (3): 511.

De Martí J, Zenou Y. 2009. Social networks. IZA Discussion Paper No. 4621.

Denny M. 2014. Social Network Analysis. University of Massachusetts, Amherst.

FORDA. 2017. Conservation of Captive Elephant in KHDTK Aek Nauli to Support Lake Toba Tourism. Retrieved from http: //www.fordamof.org/berita/post/3138. [Indonesian]

García-Amado LR, Pérez MR, Iniesta-Arandia I, Dahringer G, Reyes F, Barrasa S. 2012. Building ties: Social capital network analysis of a forest community in a biosphere reserve in Chiapas, Mexico. Ecol Soc 17 (3): 3 
Hanneman RA, Riddle M. 2005. Introduction to social network methods. University of California, Riverside, CA

Hoppe B, Reinelt C. 2010. Social network analysis and the evaluation of leadership networks. Leadership Quart 21 (4): 600-619.

IUCN. 2013. Red List of Threatened Species. Version 10. International Union for Conservation Nature. Gland, Switzerland.

Janssen M, Bodin Ö, Anderies J, Elmqvist T, Ernstson H, McAllister RR, Ryan P. 2006. Toward a network perspective of the study of resilience in social-ecological systems. Ecol Soc 11 (1): 15

Kadushin C. 2011. Understanding social network: theory, concept and finding (1st ed.). Oxford University Press, New York.

Keyes J. 2016. Enterprise 2.0: Social networking tools to transform your organization. Auerbach Publications (CRC Press), Boca Raton, FL.

Klijn EH, Steijn B, Edelenbos J. 2010. The Impact Of Network Management on Outcomes in Governance Networks. Publ Administr 88 (4): $1063-1082$.

Kontogeorgopoulos N. 2009. The role of tourism in elephant welfare in Northern Thailand. J Tourism 10 (2): 1-19.

Kunz N, Kastelle T, Moran C. 2017. Social network analysis reveals that communication gaps may prevent effective water management in the mining sector. J Cleaner Prod 148: 915-922

Kuswanda W, Situmorang ROP, Berliani K, Barus SP, Silalahi J. 2018 Conservation and Ecotourism of Elephant: A Model from KHDTK Aek Nauli. Alikodra HS, Setio P (eds). IPB Press, Bogor, Indonesia. [Indonesian]

Laohachaiboon S. 2010. Conservation for whom? Elephant conservation and elephant conservationists in Thailand. Southeast Asian Stud 48 (1): 74-95.

Lienert J, Schnetzer F, Ingold K. 2013. Stakeholder analysis combined with social network analysis provides fine-grained insights into water infrastructure planning processes. J Environ Manag 125: 134-148.

Meytasari P, Bakri S, Herwanti S. 2014. Penyusunan kriteria domestikasi dan evaluasi praktek pengasuhan gajah: studi di Taman Nasional Way Kambas Kabupaten Lampung Timur. J Sylva Lestari 2 (2): 79-88. [Indonesian]

MoEFRI. 2015. Organization Structure of Ministry of Environmental and Forestry of Republic of Indonesia, P.18/2015. [Indonesian]

Newman L, Dale A. 2005. Network structure, diversity, and proactive resilience building: a response to Tompkins and Adger. Ecol Soc 10 (1): $r 2$.

Newman L, Dale A. 2007. Homophily and agency: Creating effective sustainable development networks. Environ Dev Sustain 9 (1): 79-90.

Nyhus PJ, Tilson R. 2000. Crop-raiding elephants and conservation implications at Way Kambas National Park, Sumatra, Indonesia. Oryx 34 (4): $262-274$
Oliveira M, Gama J. 2012. An overview of social network analysis. Wiley Interdisciplinary Reviews: Data Mining and Knowledge Discovery 2 (2): 99-115.

Orrell A, Dallimore D, Krayer A, Huxley P. 2018. Social network analysis for modelling integrated social care services for older people with complex needs: a feasibility study. Intl J Integr Care 18 (s2) (A296): $1-8$

Otte E, Rousseau R. 2002. Social network analysis: A powerful strategy, also for the information sciences. J Info Sci 28 (6): 441-453.

Parr JWK, Jitvijak S, Saranet S, Buathong S. 2008. Exploratory comanagement interventions in Kuiburi National Park, Central Thailand, including human-elephant conflict mitigation. Intl $\mathbf{J}$ Environ Sustain Dev 7 (3): 293-310.

Perera BMA. 2009. The Human-elephant conflict: A review of current status and mitigation methods. Gajah 30: 41-52.

Prell C, Hubacek K, Reed M. 2009. Stakeholder analysis and social network analysis in natural resource management. Soc Nat Res 22 (6): 501-518.

Ruhnau B. 2000. Eigenvector-centrality - a node-centrality? Soc Netw 22: $357-365$.

Siegel DA. 2009. Social networks and collective action. Am J Politic Sci 53 (1): 122-138.

Singh RR, Goel K, Iyengar SRS, Gupta, S. 2015. A faster algorithm to update betweenness centrality after node alteration. Internet Math 11 (4-5): 403-420

Situmorang RO, 2018. Social capital in managing mangrove area as ecotourism by Muara Baimbai Community. Indon J For Res 5 (1): 2134

Song X, Geng Y, Dong H, Chen W. 2018. Social network analysis on industrial symbiosis: A case of Gujiao eco-industrial park. J Cleaner Prod 193: 414-423.

Tipprasert P. 2002. Elephants and ecotourism in Thailand. Giants on our hands. Proceeding of International Workshop on the Domesticated Asian Elephant. FAO Regional Office for Asia and the Pacific, Bangkok, Thailand

Wasserman S, Faust K. 1994. Social Network Analysis: Methods and Applications (Vol. 8). Cambridge University Press, Cambridge, UK.

Wu Y, Jin X. 2016. Analysis of scientific collaboration in Chinese psychiatry research. BMC Psychiatry 16 (1): 165 . DOI: 10.1186/s12888-016-0870-1

Yang HL, Tang JH. 2004. Team structure and team performance in IS development: A social network perspective. Info Manag 41: 335-349.

Zafir AWA, Magintan D. 2006. Historical review of human-elephant conflict in peninsular Malaysia. J Wildlife Park 31: 1-19. 